\title{
"CITY 2020+": assessing climate change impacts for the city of Aachen related to demographic change and health - a progress report
}

\author{
C. Schneider ${ }^{1}$, C. Balzer ${ }^{3}$, M. Buttstädt ${ }^{1}$, K. Eßer ${ }^{5}$, S. Ginski ${ }^{6}$, J. Hahmann ${ }^{4}$, G. Ketzler ${ }^{1}$, M. Klemme ${ }^{7}$, \\ A. Kröpelin ${ }^{2}$, H. Merbitz ${ }^{1}$, S. Michael ${ }^{3}$, T. Sachsen ${ }^{1}$, A. Siuda ${ }^{1}$, M. Weishoff-Houben ${ }^{3}$, M. F. Brunk ${ }^{2}$, \\ W. Dott ${ }^{3}$, H. Hofmeister ${ }^{4}$, C. Pfaffenbach ${ }^{1}$, C. Roll ${ }^{5}$, and K. Selle ${ }^{6}$ \\ ${ }^{1}$ RWTH Aachen Univ., Department of Geography, Faculty of Material Sciences and Geosciences, Germany \\ ${ }^{2}$ RWTH Aachen Univ., Construction Business and Building Services, Faculty of Civil Engineering, Germany \\ ${ }^{3}$ RWTH Aachen Univ., Institute of Hygiene and Environmental Medicine, Faculty of Medicine, Germany \\ ${ }^{4}$ RWTH Aachen Univ., Institute for Sociology, Faculty of Social Sciences and Humanities, Germany \\ ${ }^{5}$ RWTH Aachen Univ., Department of History, Faculty of Social Sciences and Humanities, Germany \\ ${ }^{6}$ RWTH Aachen Univ., Institute of Planning Theory and Urban Development, Faculty of Architecture, Germany \\ ${ }^{7}$ Univ. Münster, Governance Research and Applied Geography, Department of Geosciences, Germany
}

Received: 22 December 2010 - Revised: 9 June 2011 - Accepted: 11 August 2011 - Published: 29 September 2011

\begin{abstract}
The research initiative CITY 2020+ assesses the risks and opportunities for residents in urban built environments under projected demographic and climate change for the year 2020 and beyond, using the city of Aachen as a case study. CITY 2020+ develops strategies, options and tools for planning and developing sustainable future city structures. The investigation focuses on how urban environment, political structure and residential behaviour can best be adapted, with attention to the interactions among structural, political, and sociological configurations and their impacts on human health. The interdisciplinary research is organized in three clusters. Within the first cluster, strategies of older people exposed to heat stress, and their networks as well as environmental health risks according to atmospheric conditions are examined. The second cluster addresses governance questions, urban planning and building technologies as well as spatial patterns of the urban heat island. The third cluster includes studies on air quality related to particulate matter and a historical perspective of city development concerning environmental issues and climate variability. However, it turns out that research topics that require an interdisciplinary approach are best addressed not by pre-structuring the work into related sub-projects but through combining them according to shared methodological approaches. Examples illustrating this rather practical approach within ongoing research are presented in this paper.
\end{abstract}

\section{Introduction}

Demographers project that in Europe by 2050 , nearly $30 \%$ of the population will be over age 65 (UN World Population Prospects, 2009). An aging workforce and population combined with higher energy prices, environmental concern, and technological changes are likely to transform living and working arrangements (Grübler, 1998; Sterns, 1995).

Also by 2050 , air temperatures are projected to rise on average. However, hot summer days in Central Europe are

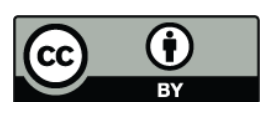

Correspondence to: C. Schneider (christoph.schneider@geo.rwthaachen.de) likely to exhibit an even accelerated increase (IPCC, 2007a). Due to an expected rise of mean air temperature resulting in a growing number of heat wave episodes in Europe (Meehl and Tebaldi, 2004) it is expected that the urban population will be increasingly exposed to adverse health effects (Luber and McGeehin, 2008; Koppe et al., 2004).

Weather and climate affect human health as well as wellbeing and productivity (Jendritzky, 2007). Heat stress, which will occur more often as a consequence of climate change has severe impacts on human health (Zebisch et al., 2005) since heat extremes can cause an increase in morbidity and mortality. This became apparent in 2003 when about 35000 people died because of the heat wave in western Europe (Koppe et al., 2003). About 700 people died 1995 in Chicago due to a 
heat wave (Semanza et al., 1996). Excessive heat events do not affect people in the same way. There are specific factors that are influencing vulnerability. Healthy living adults with existing adaptation strategies are not as jeopardized as other especially vulnerable groups such as chronically ill individuals (Mücke et al., 2009). Factors can be clustered into three groups: First, cardiovascular or respiratory diseases as well as diabetes form hazardous conditions during heat waves. Second, the consumption of medicine, drugs and alcohol is positively correlated with heat-related health stress. There are third individuals that are per se more vulnerable than others and this group consists of babies, small children and older people (Jendritzky, 1998; Haines et al., 2006; Mücke et al., 2009; UBA and DWD, 2008).

In addition to these intra-individual variables of vulnerability, research shows other risk factors. A lack of information on heat stress and adaptation strategies as well as social isolation increases vulnerability and therefore results in a higher mortality risk (Pfaff et al., 2004; Ingendahl and Thieme, 2009; Mücke et al., 2009). Technologies, e.g. air conditioning, support the human body while coping with heat stress. Extended health care is important to prepare and protect individuals at risk (Zebisch et al., 2005).

The fact that especially the combination of heat and poor air quality impinges on humans' well-being accentuates the need for assessing the health risks of the residents regarding air pollutants and anomalously high summer temperatures (Roberts, 2004). In order to estimate the population exposure to air pollution and heat load, the spatial PM and temperature distributions within the city need to be investigated. Studies show that areas with enhanced PM and thermal load are not distributed uniformly in cities but appear as hot spots with varying spatial extents (Weber, 2009; Monn et al., 1997; Taha, 1997; Oke, 1987). The health effects of air pollution have been subject to intense studies in recent years. Exposure to pollutants such as airborne particulate matter has been associated with increases in mortality and hospital admissions due to respiratory and cardiovascular disease (Brunekreef and Holgate, 2002; WHO, 2006; Thornburg et al., 2009; Yang and Omaye, 2009). To date the associations often have been made using air quality standards that only encompass PM size and concentration, but the physical and chemical characteristics of the particle and/or linked components are often neglected (Hetland et al., 2004; Dagher et al., 2005).

The recent discussion on "climate-friendly urban development" (Heiland, 2008; BMVBS and BBR, 2007; Osenberg, 2007) takes up several requests from former debates: (1) is the call for sustainable urban development (Bochnig and Selle, 1993; DIFU, 2004; Hall and Pfeiffer, 2000) and circular land use management (BBR, 2006a, b; MalburgGraf et al., 2007); (2) requests to consider demographic changes and their consequences on urban development and their implementation on site (Bürkner et al., 2007; Klemme, 2008). The local condition under which the changes are im-

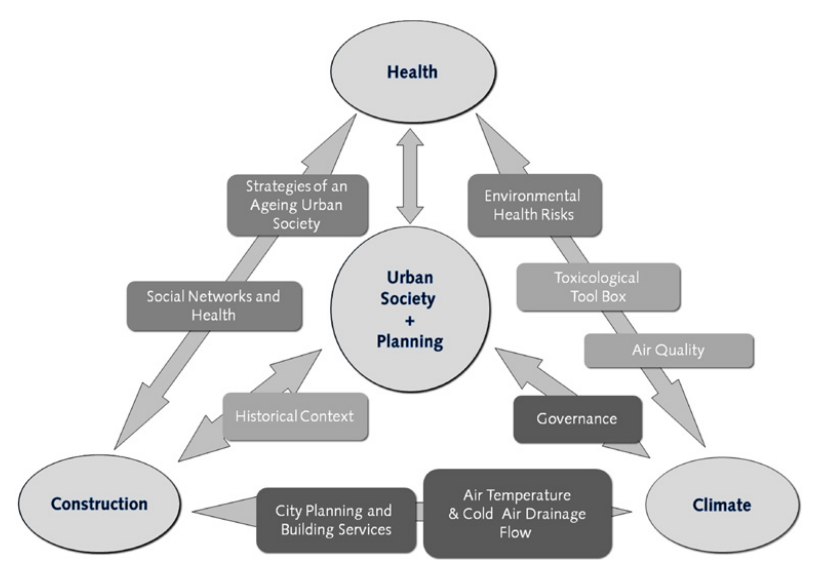

Figure 1. The structure of research project CITY 2020+. The research was initially organized into three clusters, each including three sub-projects.

plemented and the local active protagonists can be examined by a governance perspective.

Building on these studies and on previous investigations in Aachen dealing with urban climate patterns and their special characteristics (Havlik, 1981; Emonds, 1986; Ketzler, 1997; Havlik and Ketzler, 2000; Havlik, 2002), CITY 2020+ identifies the ways how microclimates in the city, health outcomes, and the urban environment are related. Within the project, the risks individuals face living and working in these conditions are assessed and new strategies are proposed based on cooperation from the fields of medicine, physical and cultural geography, sociology, history, civil engineering, planning theory and architecture for adapting the city for future needs. CITY 2020+ aims to generate strategies, to recommend options for urban planning measures and to apply tools for planning and developing sustainable future city structures. CITY 2020+ includes research projects (Fig. 1) dealing with

1. a micro-scale assessment of blockages to low-level cold-air drainage flow into the city centre by vegetation and building structures,

2. a detailed analysis of spatio-temporal air temperature patterns,

3. a micro- to meso-scale analysis of particulate matter (PM) concentrations depending on traffic, urban land use, building structure, topography, local meteorological conditions and synoptic-scale weather patterns,

4. a chemical and toxicological characterization of airborne PM and gaseous components,

5. historical viewpoints related to environment and atmospheric variability,

6. governance aspects of climate change adaptation and mitigation, 


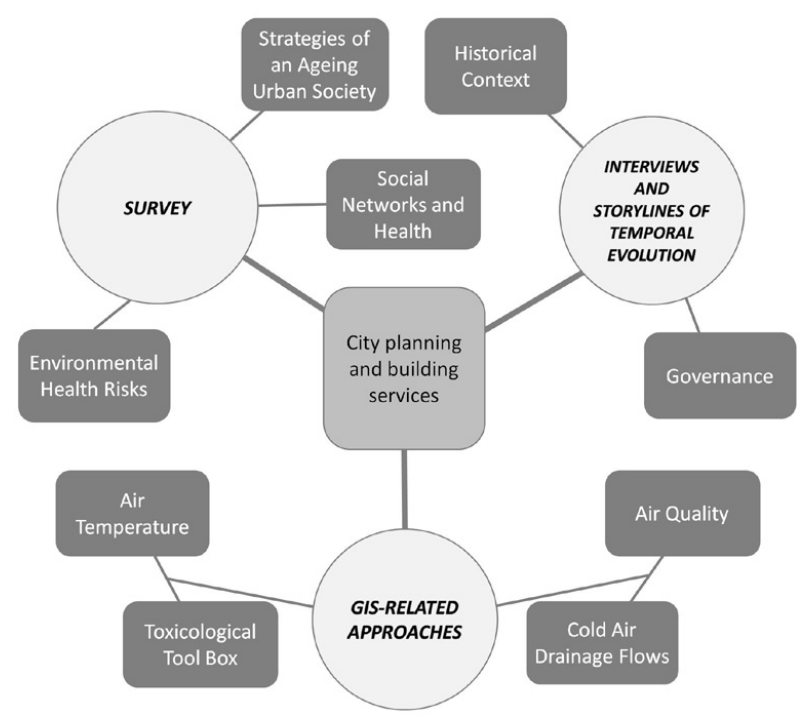

Figure 2. Project organisation related to commonly application approaches.

7. strategies of older people living and working under conditions of heat stress,

8. the importance of social networks for heat related adaptation and mitigation of individuals,

9. opportunities and risks related to building technologies for historical and modern building concepts, and

10. the impact of environmental conditions on preschool children.

Within the project CITY 2020+ it turned out that interdisciplinarity is a key issue within this highly interrelated and complex research setup. However, our experience is that interdisciplinarity does not naturally evolve within related fields but rather grows through a set of shared methods. The methods, which naturally restructure the working group of CITY 2020+, can be summarized as (1) interviews and assessments of historical lines of development, (2) surveys and (3) applications of Geographical Information Systems (GIS) (Fig. 2).

\section{Interviews and storylines of temporal evolution}

Aachen and its surroundings are considered an appropriate testbed because it can be expected that climate change impacts and demographic changes match average changes to be expected in Germany. In particular, Aachen shows a natural setting that is typical for German middle-sized cities situated on the fringe of a low mountain range adjacent to lowlands. Using the example of Aachen, observed climate data and climate projections allow for an analysis of the temporal evolution of air temperature in Aachen.
Especially affected by heat waves are residents in urban districts (Kuttler and Weber, 2008), which differ strongly from their surroundings due to surface sealing, building structure and anthropogenic heat release. We only considered air temperature as a simple indicator for heat stress because findings are more easily understood by the general public and other stakeholders. Moreover, the uncertainty in climate projections increases with the number of input variables (Koppe et al., 2004). A more detailed investigation on heat stress with an integrated biometeorological assessment would require the consideration of physiologically relevant parameters such as relative humidity, radiation or wind speed in addition to air temperature (see also Gabriel and Endlicher, 2011; Matzarakis and De Rocco, 2009; Havenith, 2005; Koppe et al., 2004; Mayer, 1997).

Observed air temperature is obtained from a weather station operated by the German Weather Service. Since 1930, air temperature is available on a daily time scale. Outputs of the regional climate model STARII (Orlowsky et al., 2008) serve for future estimations of air temperature for Aachen. Findings based on these data sets project a significant temperature increase of approximately $1 \mathrm{~K}$ for 20312060 compared to the late 20th century. Statistical analyses reveal that a shift in mean temperature to higher values entails pronounced changes in the frequency of extreme events (Mearns et al., 1984; Wigley, 2009). Extreme events regarding anomalously high air temperatures such as heat waves form a major source of social and economic disruptions (Kamal-Chaoui and Robert, 2009; Kunkel et al., 1999; Koppe et al., 2004; Hübler et al., 2007; IPCC, 2007b). These impacts might aggravate in the course of the current century due to a continuous or even accelerated temperature rise. For Europe different studies suggest heat waves to become more intense, longer lasting and more frequent in future (Frich et al., 2002; Meehl and Tebaldi, 2004; IPCC, 2007a). This prediction applies to Aachen only partly. The average duration of a heat wave as well as its intensity remained nearly constant since 1931 and is not expected to change significantly in future. However, expected is a future change in the frequency of heat waves. Simulations show that a doubling of heat wave situations is likely to occur for the worst case scenario A2. In this study, a heat wave is defined as a sequence of consecutive days on which the daily maximum temperature does not fall below $25^{\circ} \mathrm{C}$ and exceeds $30^{\circ} \mathrm{C}$ on at least three days. As the model output suggests, the temperature rise of approximately $1 \mathrm{~K}$ until the middle of the century produces at least $50 \%$ more heat days $\left(T_{\max } \geq 30{ }^{\circ} \mathrm{C}\right)$ in summer. In case of the highest-warming scenario (A2) the number of hot days more than doubles whereas a slightly stronger change can be observed for tropical nights $\left(T_{\min } \geq 20^{\circ} \mathrm{C}\right)$. Besides an expected increase in heat wave episodes, high nighttime temperatures caused by restrained nocturnal cooling (Black et al., 2004) contribute to a strengthening of thermal stress situations and might lead to adverse health effects or even excess human mortality as little relief is experienced at night 
(Koppe et al., 2004).

Archival and picture sources allow conclusions about the historical handling of inhabitants, policymakers and urban planners with environmental conditions and climate change, and a reconstruction of the perception of air and water pollution in the 19th century. An interdisciplinary study including historical maps, pictures and a digital elevation model including three-dimensional building structure examined historical changes in the conditions of cold air drainage flows in the southern part of Aachen. A considerable decrease of positive biometeorological effects of the cold air drainage flows was found in the course of urban development between 1810 and 2010. The decline can be ascribed to increased building density and built-up area. The nocturnal cooling effect for the city centre was modeled for an equinoctial situation with clear sky conditions and high temperatures $(95 \%$ percentile). The reduction of the cooling effect is $2.7 \mathrm{~K}$ and can be estimated to $3.2 \mathrm{~K}$ for an extreme summer situation with $30^{\circ} \mathrm{C}$ at sunset (Ketzler et al., 2010).

The willingness of local actors to counteract climate change in their different fields of operation is estimated on the basis of interviews and workshops by the subproject related to Governance aspects. The perception of local actors and their attitudes towards the implementation of new strategies are analysed. In summer 2010 about 15 semi-structured expert interviews were carried out. Key-players from public administration, politicians, entrepreneurs, public utilities, housing associations and other policy and decision maker are aware of the upcoming problems of climate change. In their opinion it is very necessary to act immediately. However, their own options and resources are partially limited. For example, for many property owners it is rarely possible to invest in their buildings e.g. regarding energy-saving and refurbishment. Many owners, e.g. private owners and small companies, are not able to finance the measures. In case of obvious savings things seem to become different, especially for large scale enterprises. In the light of high energy costs, companies are willing to invest in energy saving measures. Even if the effect is the same, ultimately, the main motivation is not climate protection but cost reduction (Klemme, 2011). Regarding the strategic development of settlements and housing policy, a paradigm shift towards a more sustainable landuse management cannot be deduced. Major changes of the key strategies can hardly be noticed. The strengthening of national policy frameworks and stronger involvement of all parts of the society appears to be necessary in order to face the upcoming challenges and create more sustainable city development strategies (Klemme and Selle, 2010).

In the subproject from Civil Engineering, priority is given to the improvement of the building envelope and technical facilities. Building simulations are carried out with altered parameters in order to complement existing guidelines for energy-saving construction methods combined with considerations for enhanced thermal comfort in summer. The physical buildings' characteristics, especially the thermal trans-

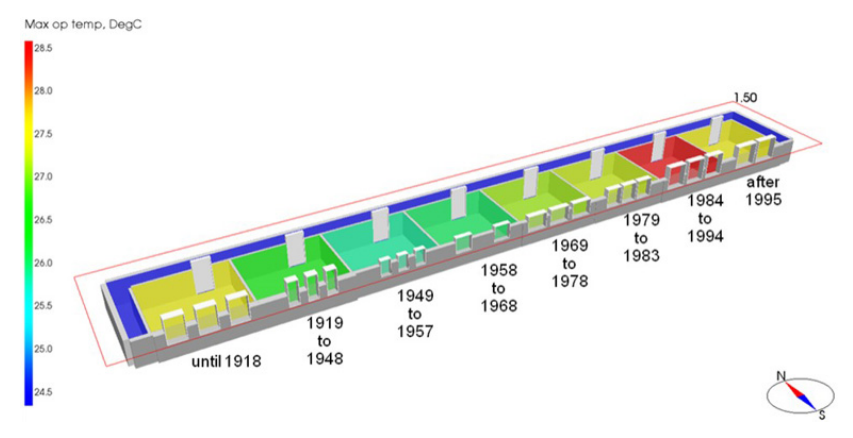

Figure 3. Maximum operative temperature depending on age and structure of buildings.

mission coefficients, were given by specifications from the German Federal Ministry Traffic, Building and Urban Development (BMVBS, 2009). These parameters are the basis for the computer simulation with a program for indoor climate and energy simulation (IDA ICE 4, www.equa.se). The assessment is combined with different settings for ventilation aiming at night-time cooling.

The simulations reveal that buildings built after 1958 include the most problematic structures in terms of hot season indoor climate. Older buildings contain more building mass with larger heat capacity to compensate for outdoor temperature increases. The more modern buildings incorporate much better insulation, aiming for energy savings during the winter periods. However, the trend toward much larger windows in modern buildings results in higher indoor temperatures in those buildings in summer (Fig. 3).

\section{Surveys}

Investigations on social networks, governance issues, building structure development and health outcomes make use of an extensive survey within the city of Aachen. To research the social situation and existing adaptation strategies concerning demographic and climate change, the fields of Cultural Geography, Sociology and Medicine conducted a comprehensive questionnaire that was sent to 8270 of Aachen's inhabitants aged 50 and older. With a response rate of $26 \%$ ( $N=2180$ questionnaires), a comparison of Aachen's urban areas concerning for example percent of residents in older age categories, percent of chronically ill residents, the distribution of the working population and the levels social isolation in different regions is possible (Siuda et al., 2010). Other relevant topics such as the living situation, heat stress and the existence of individual adaptation strategies are also part of the survey. First results show that $70 \%$ of the highly vulnerable group of respondents aged 80 and older has never received any information on heat stress or adaptation strategies by their general practitioner. The standard of the buildings people live in strongly influences the individual experience of heat stress, controlling for age and health status (BMVBS 


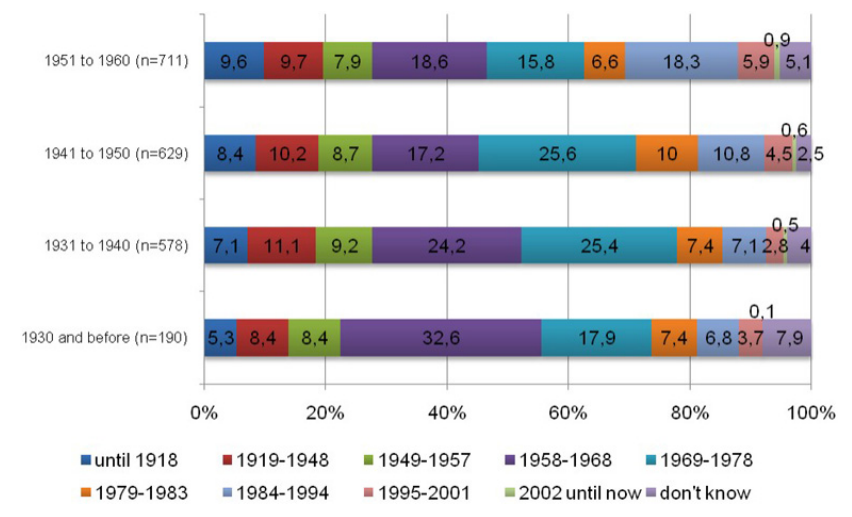

Figure 4. Year of construction of the residential buildings (coloured bars) the respondents live in, divided by age groups (yaxis representing age groups by ranges of year of birth); data from the survey on elderly people within the city of Aachen.

and BBR, 2008). The younger respondents (age 50-65) are more likely to live in an old building (built 1918 or before) or a modern building (built 1984 or later). Respondents living in buildings that were built during these periods are also more satisfied with the indoor climate during summer time. The data of our survey indicate that especially the residents aged 80 and above tend to live in buildings that are not insulated properly (built between 1958-1978), which makes them even more vulnerable to heat stress (Fig. 4). In fact, most elderly people live in buildings built from 1958 to 1978 (Fig. 5). This type of building is identified through simulation (see above) to be the most problematic building type during heat waves. A straightforward possibility to reduce heat stress in summer is to exchange old windows for anti-sun glass. However, this measure may provoke problems with fungus infestation in winter in case other parts of the building are not modernized (Brunk et al., 2010a). An energy efficient refurbishment to solve problems in summer and winter is very expensive. The return on invested capital for houses built between the 1950's and 1980's will not be achieved for twenty years (Brunk et al., 2010b).

Beside the survey of the senior population the impact of climatic change on children is researched. In a crosssectional study data on respiratory complaints, allergies and other health effects caused by air and noise pollutants are collected in the district of Aachen. Parents of about 5000 preschool children are asked to complete questionnaires during medical check-ups before school enrollment from September 2010 to June 2011. The identification of residential areas with a high proportion of vulnerable people is also relevant for the sub-projects that deal with the climatic conditions of cities. Results indicating spatial patterns can be incorporated into GIS-related approaches (see following section).

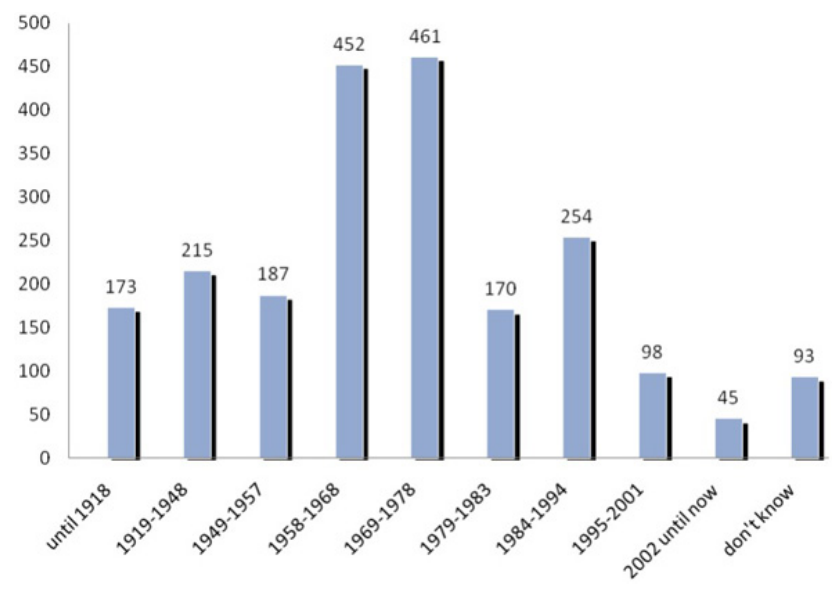

Figure 5. Numbers of buildings in different ages in Aachen.

\section{GIS-related approaches}

As an information and evaluation tool for city planners and local authorities, maps are required which combine layers of various climatic and environmental information. Urban areas with enhanced negative health effects can therefore be detected and strategies for the abatement of these drawbacks can be developed (Ren et al., 2010).

In order to identify urban areas with a high risk exposure for various urban population groups in terms of health, measurement campaigns are carried out to capture the spatial distribution of temperature and PM concentrations in the city of Aachen (Fig. 6). Since only few permanent measurement sites exist, comprehensive information on the urban temperature and PM distribution is additionally obtained from mobile measurements. Mobile temperature measurements were initiated in March 2010 in cooperation with the municipal traffic company. The spatial and temporal pattern of the UHI and its possible enhancement by climate change is addressed employing a unique setup using GPS devices and temperature data loggers fixed to several public transport units running along different traverses across the city (Buttstädt et al., 2011). During scheduled public bus rides, temperature is recorded simultaneously throughout the day. This method provides a high spatial and temporal resolution, is cost-effective and time-saving, and can easily be transferred to other regions. Currently, temperature data from 15 measurement days are available. First analyses confirm the principally known influence of urban structures. While densely built-up areas show positive temperature anomalies with regard to temperature observations obtained from the suburban weather station Aachen-Hörn, lower temperatures occur mainly in areas covered by forest and suburban sites (Buttstädt et al., 2010). Additionally, the large data base allows detailed statistical analyses of urban structures and their temperature effect. Especially building area and building height prove to contribute to a positive 


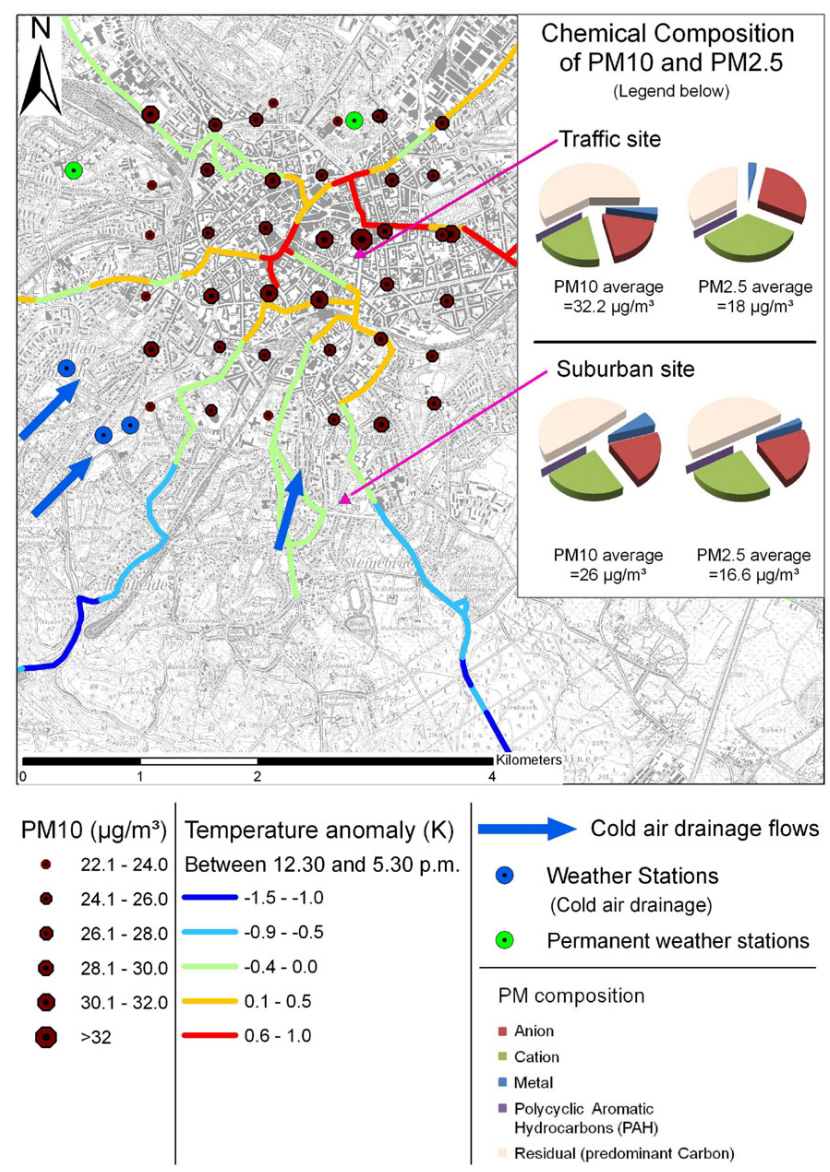

Figure 6. GIS-based investigations covering spatial PM and temperature distribution, cold air drainage flows and chemical composition of $\mathrm{PM}_{10}$ and $\mathrm{PM}_{2.5}$ in the city of Aachen.

relation $\left(R^{2} \approx 0.67\right)$ between temperature and different spatial variables, indicated through multiple regression. The intraurban temperature distribution and its influencing factors will be used to identify thermally affected urban districts.

A dense net of 40 urban particulate matter (PM) measurement sites is operated in order to obtain the spatial pattern of PM concentration depending on spatial variables and meteorological condition (Fig. 6). A connective study investigates the present spatial distribution of PM concentrations in Aachen. The population exposure to harmful particles is investigated by small and meso-scale measurements and geo-statistical approaches (Merbitz, 2010). Mobile measurements of PM concentrations are carried out within suburban, urban and inner city measurement campaigns since summer 2009. $\mathrm{PM}_{10}$ and $\mathrm{PM}_{2.5}$ concentrations are measured at each measurement site as 1-minute averages over a total period of $10 \mathrm{~min}$ at a height of $1.6 \mathrm{~m}$ using an optical device (Environmental Dust Monitor 107, GRIMM, Germany). During a 7 month measurement campaign covering the period between September 2009 and March 2010 at each of the 40 sites between 18 and 20 measurements were carried out in order to obtain average $\mathrm{PM}_{10}$ and $\mathrm{PM}_{2.5}$ distributions during the cold season. Small- and meso-scale spatio-temporal variability of $\mathrm{PM}_{10}$ and $\mathrm{PM}_{2.5}$ are assessed and related to parameters such as traffic, building structure, topography, land use and meteorology. Especially for the coarse particle fraction $\left(\mathrm{PM}_{10-2.5}\right)$ a large spatial variability can be revealed, which is attributed to the influence of traffic related sources. These findings are in accordance to results of a study in Berlin showing large spatial variability for coarse particles while small particles $\left(\mathrm{PM}_{2.5}\right)$ showed more temporal than spatial variability, related to meteorological influences (Wolf-Benning et al., 2009). Results of mobile PM and temperature measurements suggest a strong dependence of temperature and PM on spatial variables, which will further be used as predictors for the identification of urban areas where both high temperatures and high levels of particulate air pollution coincide. It has been reported that PM has largest effects on mortality on hot days due to increased physiological stress and an altered physiological response to toxic agents (Roberts, 2004). In the inner city, especially the traffic density, building height and building density show significant positive correlations with PM levels and air temperature. Regarding the distribution of these parameters, areas with high risk of heat load and poor air quality are identified by means of GIS-based spatial analyses (Merbitz et al., 2011). Moreover, the urban wind field is investigated in order to identify areas with degraded ventilation conditions exacerbating the dilution of air pollutants (Merbitz et al., 2010). Distributions of PM and potential hot spots of heat stress over the total urban area are derived from the distribution of the spatial predictors applying a multiple land use regression analysis (Briggs et al., 1997, 2000; Clougherty et al., 2008; Hoek et al., 2008; Johnson et al., 2010). Models will be developed for the short-term forecast of PM levels and for the assessment of the future development of PM pollution in urban areas, considering meteorological influences (Merbitz, 2009) and climatic change.

Beside the meteorological variables, the content and composition of air pollutants continues to pose a significant threat to human health (WHO, 2006; Kinney, 2008). In this context the subproject Environmental Medicine characterizes the chemical composition and toxicological effects of gaseous and particulate airborne pollutants. This includes a full determination of inorganic and organic components, such as metals, salt, ions, total carbon (TC) and polycyclic aromatic hydrocarbons (PAH). The stationary PM10 and $\mathrm{PM}_{2.5}$ sampling for the chemical analysis at the urban and suburban site was carried out according to DIN EN 12341 and DIN EN 14907. Analog to the geo-statistical analyses the chemical investigation reveals strong differences in the chemical composition amongst the sampling sites (Fig. 7). The main inorganic components of the airborne particles are $\mathrm{Al}, \mathrm{Ca}, \mathrm{Fe}, \mathrm{Zn}, \mathrm{Mg}$, $\mathrm{NO}_{3}^{-}, \mathrm{SO}_{4}^{2-}$. Highest concentrations of the health relevant substance PAH were found at the traffic site. An influence of the particle size on the PAH level could not be detected. The 


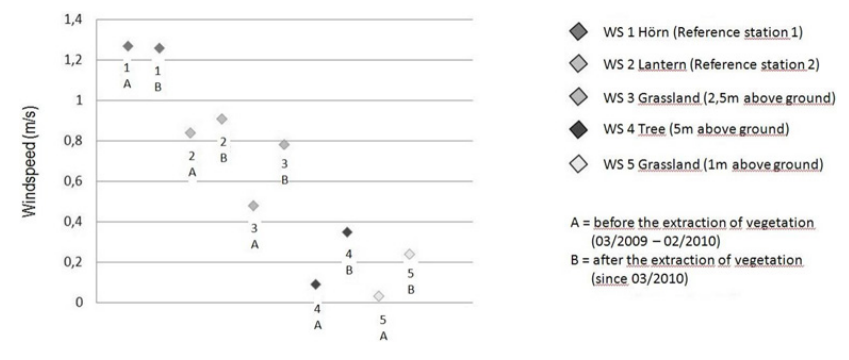

Figure 7. Average wind speed at different weather stations after the extraction of vegetation during periods with westerly winds at the reference station Aachen-Hörn (1) and a wind speed between 1 and $1.5 \mathrm{~m} \mathrm{~s}^{-1}$ as a precondition for the existence of cold air drainage flow at the suburban valley stations (2-5).

combined effects of various components within PM need to be investigated in the future in more detail.

An important factor for the mitigation of PM pollution and heat is the flow of clean air, which in the city of Aachen is provided by cold air drainage, due to the valley situation. Concentrating on the diminution of thermal load situations, cold air drainage flows are identified and the amount and thickness of cold air are determined. In order to model cold air drainage flow, one sub-project focuses additionally on drawbacks that influence the flow characteristics (Sachsen et al., 2010). The analysis of the cold air drainage flow is investigated in two consecutive years with a clearing of vegetation stands in the beginning of the second year early in 2010. The investigation area in a southern suburban area of Aachen covers valleys with a very high relevance for the reduction of inner urban temperatures and air quality problems (Ketzler, 2002). Within two of these valleys, weather stations have been set up in order to obtain detailed information about the characteristics and behaviour of cold air drainage flows. The extraction of small vegetation stands at the measurement sites permit a closer look on how vegetation affects drainage flows in different heights. In order to compare the different data sets before and after the extraction a reference station (Weather station Aachen-Hörn) in Aachen is used. Measurements of wind speed and direction before and after the extraction indicate a considerable influence of porosity, height and formation on drainage flows. Figure 7 shows increased wind speeds at the weather stations in the valley within two measurement periods, one before and one after the extraction of vegetation. In many cases, areas of limited cold air influence are also affected by inferior air quality.

\section{Conclusion and outlook}

Cooperations between the fields of medicine, geography, sociology, history, civil engineering, and architecture provide the basis for proposing new strategies for adapting the city for future needs. The application of common methods concatenating different disciplines allow for a strong collabora- tion and better understanding of multidisciplinary interrelations. The results of the several fields are combined in maps to identify urban areas in which the population is extremely vulnerable regarding multiple stressors, e.g. air temperature, high level of PM and its composition, building structure and concentration of elderly persons or people that are socially isolated. While climate mitigation strategies are well established and accepted approaches, climate adaptation has not been adequately considered yet. There seem to be considerable conflicts of interests related to economic questions, the environment, and the expansion of under roof areas etc. Due to the complexity of the research topic it is conceivable to integrate other disciplines such as traffic planning, urban hydrology and economics in future research.

Acknowledgements. The Project CITY 2020+ is part of the interdisciplinary Project House HumTec (Human Technology Centre) at RWTH Aachen University funded by the Excellence Initiative of the German federal and state governments through the German Research Foundation (Deutsche Forschungsgemeinschaft, DFG).

Edited by: T. Cegnar

Reviewed by: W. Endlicher and another anonymous referee

\section{SC $\mid$ nat $\# \begin{aligned} & \text { The publication of this article is sponsored } \\ & \text { by the Swiss Academy of Sciences. }\end{aligned}$}

\section{References}

Black, E., Blackburn, M., Harrison, G., Hoskins, B., and Methven, J.: Factors contributing to the summer 2003 European heatwave, Weather, 59, 217-223, 2004.

BBR (Bundesamt für Bauwesen und Raumordnung): Perspektive Flächenkreislaufwirtschaft Kreislaufwirtschaft in der städtischen/stadtregionalen Flächennutzung - Fläche im Kreis. Ein ExWoSt-Forschungsfeld. Ergebnisse einer Akteursbefragung zur Flächenkreislaufwirtschaft in den Planspielregionen Stuttgart, Mölln, Rheinhessen-Nahe, Duisburg und Nordthüringen, Berlin, 2006a.

BBR (Bundesamt für Bauwesen und Raumordnung): Perspektive Flächenkreislaufwirtschaft. Theoretische Grundlagen und Planspielkonzeption. Band 1 der Sonderveröffentlichungsreihe zum ExWoSt-Forschungsfeld "Fläche im Kreis, Bonn, 2006b.

BMVBS (Bundesministerium für Verkehr, Bau und Stadtentwicklung): Bekanntmachung der Regeln zur Datenaufnahme und Datenverwendung im Wohngebäudebestand, Berlin, 2009.

BMVBS (Bundesministerium für Verkehr, Bau und Stadtentwicklung) and BBR (Bundesamt für Bauwesen und Raumordnung) (Eds.): Raumentwicklungsstrategien zum Klimawandel, Dokumentation der Fachtagung am 30. Oktober 2007 im Umweltforum Berlin, Bonn, Berlin, 2007.

BMVBS (Bundesministerium für Verkehr, Bau und Stadtentwicklung) and BBR (Bundesamt für Bauwesen und Raumordnung) (Eds.): Folgen des Klimawandels: Gebäude und Baupraxis in Deutschland, BBR-Online-Publication, 10, 2008. 
Bochning, S. and Selle, K. (Eds.): Freiräume für die Stadt. Sozial und ökologisch orientierter Umbau von Stadt und Region, Bauverlag, Wiesbaden, 1993.

Briggs, D. J., Collins, S., Elliott, P., Fischer, P., Kingham, S., Lebret, E., Pryl, K., van Reeuwijk, H., Smallbone, K., and van der Veen, A.: Mapping urban air pollution using GIS: a regression-based approach, Int. J. Geogr. Inf. Sci., 11(7), 699-718, 1997.

Briggs, D. J., Hoogh, C. de, Gulliver, J., Wills, J., Elliott, P., Kingham, S., and Smallbone, K.: A regression-based method for mapping traffic-related air pollution application and testing in four contrasting urban environments, Sci. Total Environ., 253(1-3), 151-167, 2000.

Brunekreef, B. and Holgate, S. T.: Air pollution and health, Lancet, 360, 1233-1242, 2002.

Brunk, M., Dott, W., Balzer, C., Kröpelin, A., and Michael, S.: Entstehung von Schimmelpilzbelastung in Gebäuden in Abhängigkeit vom Lüftungsverhalten, Umweltmedizin in Forschung und Praxis, 15, 295-296, 2010a.

Brunk, M., Kröpelin, A., and Möllenhoff, N.: Energy efficient refurbishments - The necessity of political incentive systems, The REHVA European HVAC Journal, 47, 28-33, 2010b.

Bürkner, H.-J., Berger, O., Luchmann, C., and Tenz, E.: Der demographische Wandel und seine Konsequenzen für Wohnungsnachfrage, Städtebau und Flächennutzung, 2007.

Buttstädt, M., Sachsen, T., Ketzler, G. and Schneider, C.: Innerstädtische Temperaturverteilung in Aachen, Aachener Geographische Arbeiten, 47, 60-68, 2010.

Buttstädt, M., Sachsen, T., Ketzler, G., Merbitz, H., and Schneider, C.: A new approach for highly resolved air temperature measurements in urban areas, Atmos. Meas. Tech. Discuss., 4, 10011019, doi:10.5194/amtd-4-1001-2011, 2011.

Clougherty, J. E., Wright, R. J., Baxter L. K., and Levy, J. I.: Land use regression modeling of intra-urban residential variability in multiple traffic-related air pollutants, Environ. Health, 717, doi:10.1186/1476-069X-7-17, 2008.

Dagher, Z., Garçon, G., Gosset, P., Ledoux, F., Surpateanu, G., Courcot, D., Aboukais, A., Puskaric, E., and Shirali, P.: Proinflammatory effects of Dubkerque city air pollution particulate matter 2.5 in human epithelial lung cells (L132) in culture, J. Appl. Toxicol., 25, 166-175, 2005.

DIFU (Deutsches Institut für Urbanistik) (Eds.): Kommunen auf dem Weg zur Nachhaltigkeit, Köln, 2004.

DIN EN 12341: Air quality - Determination of the PM10 fraction of suspended particulate matter - Reference method and field test procedure to demonstrate reference equivalence of measurement methods, German version EN 12341, 1998.

DIN EN 14907: Ambient air quality - Standard gravimetric measurement method for the determination of the PM2.5 mass fraction of suspended particulate matter, German version EN 14907, 2005.

Emonds, H.: Klimatologische Beurteilungsgrundlagen zur Berücksichtigung der Luftreinhaltung bei der städtebaulichen Planung in Tallagen, Aachen, 1986.

Frich, P., Alexander, L. V., Della-Marta, P. M., Gleason, G., Haylock, M., Klein Tank, A. M. G., and Peterson, T.: Observed coherent changes in climatic extremes during the second half of the twentieth century, Clim. Res., 19, 193-212, 2002.

Gabriel, K. and Endlicher, W.: Urban and rural mortality during heat waves in Berlin and Brandenburg, Germany, Environ. Pol- lut., 159, 2044-2050, doi:10.1016/j.envpol.2011.01.016, 2011.

Grübler, A.: Technology and Global Change, Cambridge, 1998.

Haines, A., Kovats, R. S., Campbell-Lendrum, D., and Corvalan, C.: Climate Change and human health: impacts, vulnerability, and mitigation, Lancet, 367, 2101-2109, 2006.

Hall, P. and Pfeiffer, U.: Urban 21. Der Expertenbericht zur Zukunft der Städte, Stuttgart, München, 2000.

Havenith, G.: Temperature regulation, heat balance and climatic stress, in: Extreme weather events and public health responses, edited by: Kirch, W., Menne, B., and Bertollini, R., 69-80, 2005.

Havlik, D.: Großstädtische Wärmeinsel und Gewitterbildung ein Beispiel anthropogener Klimamodifikation, Aachener Geographische Arbeiten, 14, 91-122, 1981.

Havlik, D.: Das Klima von Aachen, Aachener Geographische Arbeiten, 36, 1-20, 2002.

Havlik, D. and Ketzler, G.: Gesamtstädtisches Klimagutachten Aachen, Aachen, 2000.

Heiland, S.: Der Klimawandel als Herausforderung für die Landschaftsplanung. Probleme, Fragen und Lösungsansätze, Naturschutz und Landschaftsplanung, 40(2), 37-41, 2008.

Hetland, R. B., Cassee, F. R., Refsnes, M., Schwarze, P. E., Lag, M., Boere, A. J. F., and Dybing, E.: Release of inflammatory cytokines, cell toxicity and apoptosis in epithelial lung cells after exposure to ambient air particles of different size fractions, Toxicol. In Vitro, 18, 203-218, 2004.

Hoek, G., Beelen, R., Hoogh, K. de, Vienneau, D., Gulliver, J., Fischer, P., and Briggs, D.: A review of land-use regression models to assess spatial variation of outdoor air pollution, Atmos. Environ., 42(33), 7561-7578, 2008.

Hübler, M., Klepper, G., and Peterson, S.: Costs of Climate Change. The effects of rising temperatures on health and productivity in Germany, Kiel Working Paper 1321, 2007.

Ingendahl, B. and Thieme, I.: Gesundheitliche Effekte des Klimawandels - Aufklärung und Bewusstseinsbildung als wesentlicher Bestandteil von Anpassungsmaßnahmen, UMIDThemenheft Klimawandel und Gesundheit, 3, 5-7, 2009.

IPCC: Climate Change 2007: The Physical Science Basis, Contribution of Working Group I to the Fourth Assessment Report of the Intergovernmental Panel on Climate Change, edited by: Solomon, S., Qin, D., Manning, M., Chen, Z., Marquis, M., Averyt, K. B., Tignor, M., and Miller, H. L., Cambridge University Press, Cambridge, United Kingdom, New York, 2007a.

IPCC: Climate Change 2007: Impacts, Adaptation and Vulnerability, Contribution of Working Group II to the Fourth Assessment Report of the Intergovernmental Panel on Climate Change, edited by: Parry, M. L., Canziani, O. F., Palutikof, J. P., van der Linden, P. J., and Hanson, C. E., Cambridge University Press, Cambridge, 2007b.

Jendritzky, G.: Einwirkungen von Klimaänderungen auf die Gesundheit des Menschen in Mitteleuropa, in: Klimastatusbericht 1998, edited by: DWD (Deutscher Wetterdienst), 7-17, 1998.

Jendritzky, G.: Folgen des Klimawandels für die Gesundheit, in: Der Klimawandel - Einblicke, Rückblicke, Ausblicke, edited by: Endlicher, W. and Gerstengarbe, F.-W., Berlin/Potsdam, 108119, 2007.

Johnson, M., Isakov, V., Touma, J. S., Mukerjee, S., and Ozkaynak, H.: Evaluation of land-use regression models used to predict air quality concentrations in an urban area, Atmos. Environ., 44(30), 
3660-3668, 2010.

Kamal-Chaoui, L. and Robert, A. (Eds): Competitive cities and climate change, OECD Regional Development Working Papers, 2, 2009.

Ketzler, G.: Vergleichende Untersuchungen der Temperaturverhältnisse in Städten unter besonderer Berücksichtigung der Temperaturänderungsraten, Aachener Geographische Arbeiten, 31, 234 pp., 1997.

Ketzler, G.: Untersuchungen an Kaltluftströmen in kleinen stadtnahen Tälern, Aachener Geographische Arbeiten, 36, 21-64, 2002.

Ketzler, G., Eßer, K., and Sachsen, T.: Veränderung von Belüftungsfunktionen durch lokalen Kaltluftabfluss im Zuge historischer Stadtentwicklung - eine Modellstudie Aachen 18102010, Aachener Geographische Arbeiten, 47, 77-98, 2010.

Kinney, P. L.: Climate Change, Air Quality, and Human Health, Am. J. Prev. Med., 35(5), 459-467, 2008.

Klemme, M.: Wohnflächenentwicklung unter veränderten Rahmenbedingungen: Öffentliche Akteure zwischen Neubau und Bestand, in: Bestand? Perspektiven für das Wohnen in der Stadt, edited by: Schmitt, G. and Selle, K., Dortmund, 2008.

Klemme, M.: Akteure der lokalen Klimapolitik im Spannungsfeld von Persitenzen und Eigenlogiken, in: Anpassung an den Klimawandel - regional umsetzen!, edited by: Frommer, B., Buchholz, F., and Böhm, H. R., oekom-Verlag, München, 121-138, 2011.

Klemme, M. and Selle, K.: Gutes Klima? Klimawandel und lokale Klimapolitik aus der Governance-Perspektive. Ein Dialog in Aachen, PT_Materialien 25, 2010.

Koppe, C., Jendritzky, G., and Pfaff, G.: Die Auswirkungen der Hitzewelle 2003 auf die Gesundheit, in: Klimastatusbericht 2003, edited by: DWD (Deutscher Wetterdienst), 152-162, 2003.

Koppe, C., Kovats, S., Jendritzky, G. and Menne, B.: Heat waves: Risks and responses, Copenhagen, 2004.

Kunkel, K. E., Pielke, R. A., and Changnon, S. A.: Temporal fluctuations in weather and climate extremes that cause economic and human health impacts: a review, B. Am. Meteorol. Soc., 80(6), 1077-1098, 1999.

Kuttler, W. and Weber, S.: Urban climate and global climate change - a case study of the 'Ruhr area', Germany, Berichte des Meteorologischen Instituts der Universität Freiburg, 18, 313-319, 2008.

Luber, G. and McGeehin, M.: Climate change and extreme heat events, Am. J. Prev. Med., 35(5), 429-435, 2008.

Malburg-Graf, B., Renn, O., and Ulmer, F.: Strategien und Instrumente zur Reduzierung des Flächenverbrauchs - Ergebnisse des Ziel-30-ha-Projektes des Rates für Nachhaltige Entwicklung, in: Flächenmanagement als Instrument der integrativen Planung für ländliche Räume und der kommunalen Innenentwicklung - Beiträge des 2. Hochschultages 2007 "Strukturentwicklung ländlicher Raum in Baden-Württemberg”, edited by: MalburgGraf, B., Stuttgarter Geographische Studien, 140, 85-99, 2007.

Matzarakis, A. and De Rocco, M.: Thermal bioclimate in Strasbourg - the 2003 heat wave, Theor. Appl. Climatol., 98, 209$220,2009$.

Mayer, H.: Biometeorologische Auswirkungen des Stadtklimas, VDI Berichte, 1330, 109-126, 1997.

Mearns, L. O., Katz, R. W., and Schneider, H.: Extreme hightemperature events: changes in their probabilities with changes in mean temperature, J. Clim. Appl. Meteorol., 23, 1601-1613, 1984.

Meehl, G. and Tebaldi, C.: More intense, more frequent, and longer lasting heat waves in the 21st century, Nature, 305, 994-997, 2004.

Merbitz, H.: Feinstaubkonzentration in Abhängigkeit von Witterung und Großwetterlagen im Raum Aachen, Aachener Geographische Arbeiten, 46, 121-134, 2009.

Merbitz, H.: Feinstaubbelastung in Aachen und in der Euregio Maas-Rhein, Aachener Geographische Arbeiten, 47, 48-59, 2010.

Merbitz, H., Ketzler, G., and Schneider, C.: Untersuchungen zu den Windverhältnissen im Innenstadtbereich von Aachen, Aachener Geographische Arbeiten, 47, 99-118, 2010.

Merbitz, H., Buttstädt, M., Michael, S., Dott, W., and Schneider, C.: GIS-based identification of spatial variables enhancing heat and poor air quality in urban areas, Appl. Geogr., doi:10.1016/j.apgeog.2011.06.008, 2011.

Monn, C., Carabias, V., Junker, M., Waeber, R., Karrer, M., and Wanner, H. U.: Small-scale spatial variability of particulate matter $<10 \mu \mathrm{m}$ (PM10) and nitrogen dioxide, Atmos. Environ., 31(15), 2243-2247, 1997.

Mücke, H.-G., Klasen, J. Schmoll, O., and Szewzyk, R.: Gesundheitliche Anpassung an den Klimawandel, Umweltbundesamt, Deutscher Wetterdienst (Eds.), Dessau-Roßlau, 2009.

Oke, T. R.: Boundary layer climates, Routledge, New York, 1987.

Orlowsky, B., Gerstengarbe, F.-W., and Werner, P. C.: A resampling scheme for regional climate simulations and its performance compared to a dynamical RCM, Theor. Appl. Meteorol., 92, 209-223, 2008.

Osenberg, H.: Raumordnung als Teil einer nationalen Anpassungsstrategie an den Klimawandel, in: Raumentwicklungsstrategien zum Klimawandel, Dokumentation der Fachtagung am 30. Oktober 2007 im Umweltforum Berlin, edited by: BMVBS (Bundesministerium für Verkehr, Bau und Stadtentwicklung) and BBR (Bundesamt für Bauwesen und Raumordnung), Bonn, Berlin, 7, 2007.

Pfaff, G., Koppe, C., and Jendritzky, G.: Hitzewellen und extreme Klimaereignisse - Herausforderungen für das Gesundheitswesen, Epidemiologisches Bulletin, 25, 200-204, 2004.

Ren, C., Ng, E. Y., and Katzschner, L.: Urban climatic map studies: a review, Int. J. Climatol., doi:10.1002/joc.2237, 2010.

Roberts, S.: Interactions between particulate air pollution and temperature in air pollution mortality time series studies, Environ. Res., 96(3), 328-337, 2004.

Sachsen, T., Ketzler, G., and Käsmacher, O.: Stadt- und geländeklimatologische Untersuchungen in Aachen und Umgebung, Aachener Geographische Arbeiten, 47, 39-47, 2010.

Semanza, J. C., Rubin, C. H., Falter, K. H., Selanikio, J. D., Flanders, W. D., Howe, H. L., and Wilhelm, J. L.: Heat-Related Deaths During the July 1995 Heat Wave in Chicago, New Engl. J. Med., 335(2), 84-90, 1996.

Siuda, A., Hahmann, J., Hofmeister, H., and Pfaffenbach, C.: Hitzegefährdete Bevölkerungsgruppen in Aachen, Aachener Geographische Arbeiten, 47, 69-76, 2010.

Sterns, H. L.: The Aging Worker in a Changing Environment: Organizational and Individual Issues, J. Vocat. Behav., 47, 248-268, 1995.

Taha, H.: Urban climates and heat islands. albedo, evapotranspi- 
ration, and anthropogenic heat, Energ. Buildings, 25, 99-103, 1997.

Thornburg, J, Rodes, C. E., Lawless, P. A., and Williams, R.: Spatial and temporal variability of outdoor coarse particulate matter mass concentrations measured with a new coarse particle sampler during the Detroit Exposure and Aerosol Research Study, Atmos. Environ., 43(28), 4251-4258, 2009.

UBA (Umweltbundesamt) and DWD (Deutscher Wetterdienst): Klimawandel und Gesundheit, Informationen zu gesundheitlichen Auswirkungen sommerlicher Hitzewellen und Tipps zum vorbeugenden Gesundheitsschutz, Dessau-Roßlau, 2008.

UN World Population Prospects (Population Division of the Department of Economic and Social Affairs of the United Nations Secretariat, World Population Prospects): The 2009 Revision, http://esa.un.org/unpd/wpp/unpp/p2k0data.asp, 2009.

Weber, S.: Spatio-temporal covariation of urban particle number concentration and ambient noise, Atmos. Environ., 43(34), 5518-5525, 2009.
Wigley, T. M. L.: The effect of changing climate on the frequency of absolute extreme events, Clim. Change, 97, 67-76, 2009.

Wolf-Benning, U., Draheim, T., and Endlicher, W.: Spatial and temporal differences of particulate matter in Berlin, Special Issue on Urban Air Pollution: Problems, Control Technologies and Management Practices, International Journal of Environment and Waste Management, 4(1/2), 3-16, 2009.

WHO (World Health Organisation): WHO Air quality guidelines for particulate matter, ozone, nitrogen dioxide and sulfur dioxide, 2006.

Yang, W. and Omaye, S. T.: Air pollutants, oxidative stress and human health, Mutat. Res.-Gen. Tox. En., 674, 45-54, 2009.

Zebisch, M., Grothmann, T., Schröter, D., Hasse, C., Fritsch, U., and Cramer, W.: Klimawandel in Deutschland. Vulnerabilität und Anpassungsstrategien klimasensitiver Systeme, Dessau, 2005. 